\title{
Raising Children to Speak Their Heritage Language in the USA: Roles of Korean Parents
}

\author{
Guang-Lea Lee \\ Department of Teaching and Learning, Old Dominion University, Norfolk, Virginia, USA \\ Abha Gupta \\ Department of Teaching and Learning, Old Dominion University, Norfolk, Virginia, USA
}

\begin{abstract}
Parents play a significant role in fostering Korean-American children's heritage language learning. This qualitative inquiry investigates Korean immigrant parents' beliefs and the language practices they engage in to raise their children to speak Korean. Based on questionnaires completed by $\mathbf{4 0}$ parents and in-depth, open-ended interviews with 5 parents, this study specifically focuses on Korean parents residing in an area with a low Korean immigrant population and how they perceive, foster, and advocate for their children's Heritage Language (HL) learning. The findings show that parents play crucial roles as active advocates of their children's HL learning and positive belief in HL maintenance, making best efforts to help their children see the value of learning. In addition, the findings show that parents serve as HL educators, who create an HL learning environment, instruct HL reading and writing, and incorporate digital tools and popular culture for HL learning.
\end{abstract}

Index Terms-immigrant families, heritage language, bilingual learning, biliteracy development, Korean immigrant parents

\section{INTRODUCTION}

Children who have an opportunity to maintain their heritage language while growing up, become bilingual and biliterate which in turn can impact positively on their cognitive, intellectual, and identity development (Choi, Lee, \& Oh, 2018; Jia, Chen, Kim, Chan, \& Jeung, 2014; Park \& Sarkar, 2007; Yang, Yang \& Lust, 2011). However, current research shows that there is an increasing number of Heritage Language (HL) learners from linguistically minoritized families, who experienced first-language loss. The narrow conception of the term, HL learner, refers to a child who is "raised in a home where a non-English language is spoken by one who speaks or merely understands the heritage language, and who is to some degree bilingual in English and the heritage language" (Valdés, 2001, p. 38). Considering a great variation in the level of language proficiency among heritage language learners (Polinsky \& Kagan, 2007), we will employ a broad concept of HL learner. In this paper, HL learners refer to children who have Korean heritage and speak Korean with at least one of the parents regardless of their proficiency in Korean.

Korean-American families tend to experience their language shift from Korean to English despite the fact that they are predominantly recent immigrants and largely a Korean-speaking group (Cho 2000). Language attrition and eventual loss of heritage language can have negative consequences for HL learners, including identity crisis and diminished cultural awareness and knowledge (Law, 2015). Furthermore, loss of the heritage language has a profound effect on immigrant children's relationships with their families and communities, and children who experience first-language loss often experience a fear of rejection from their ethnic community which can cause educational difficulties (Budiyana, 2017; Sánchez-Muñoz, 2016; Wong Fillmore,1991).

Similar to HL learners from other ethnic backgrounds, many school-aged Korean HL learners lack HL proficiency (Law, 2015; Shin, 2005; Shin, 2002). Upon entering English dominant school and society, these children feel more pressured to focus on developing English than maintaining HL (de Jong, 2011; Jia et al., 2014; Shin, 2005; Wong Fillmore, 1991). Local heritage language school can help immigrant children learn and develop their HL, share their cultural identities, and maintain their culture (Cho, 2000; Cho et al., 1997; Fishman, 2001; Lee, 2002; Lu, 2001; Shibata, 2000). However, areas in the United States with a low Korean population have few HL learning resources or educational programs available for Korean HL learners. It is therefore essential that immigrant parents, as the first HL contact and main source of HL, support their children's HL development and maintenance at home (Brown, 2011).

As previous studies have shown, home is where bilingual learning and biliteracy development begin (DeCapua \& Wintergerst, 2009; Li, 2006; García \& Kleifgen, 2018; Ro \& Cheatham, 2009). As Lee and Wright (2014) argue, teaching heritage language starts at home with parents. While there are a number of studies that discovered immigrant parents' positive perspectives on teaching HL to their children, little is known about how they help their children understand the value of learning and maintaining HL. This study contributes to the field of HL education by showing how Korean immigrant parents' advocate for HL teaching and enact different teaching strategies to promote their children's HL learning 
Since many prior studies on HL learning have focused on metropolitan cities with a higher Korean population (Jo \& Lee, 2016; You, 2005), it is significant that this study pays close attention to Korean parents in the southeastern region of Virginia, United States, which has a low Korean immigrant population, limited need for Korean usage, and unavailability of HL resources for HL instruction. Much of the existing research on Korean heritage language learners focuses on Koreans living in metropolitan areas with a high density of Korean ethnic communities (You, 2005). In contrast, participants in the present study, living in an area with a very low Korean population, have little exposure to Korean ethnic communities or Korean literacy resources. By exploring beliefs and specific strategies that Korean immigrant parents engage their children in at home, we strive to push back on the deficit views on immigrant parents and argue that it is essential to examine how immigrant parents support their children's bilingualism and biliteracy in and out of the school setting.

\section{REVIEW OF LITERATURE}

\section{A. Fostering Korean-American Children's Heritage Language Learning at Home}

The home environment is extremely important for children's language and literacy learning because there, children engage in a wide range of effective activities, such as shared reading, play-based activities, and writing (Han \& Neuharth-Pritchett, 2014). In an immigrant household, family plays a crucial role in developing their children's HL and supporting bilingualism (De Houwer, 2007; Kang, 2013; Zhang \& Slaughter-Defore, 2009) because how a family communicates, and what they do at home impacts children's language use and proficiency.

To foster children's HL, immigrant families engage in a wide range of practices (García \& Kleifgen, 2018; Law, 2015), which are tied to the families' past experiences, history, and culture. For example, Li (2002)'s ethnographic research on home literacy practices of four Chinese immigrant families in Canada demonstrated that parent-child interactions, parental support for literacy learning, and family activities played important roles in Chinese immigrant children's heritage language learning. In the study, Li (2002) described a variety of home literacy practices that fostered the children's maintenance of heritage language, including creating a bilingual wordlist, writing letters to family members, and reciting poems in Chinese.

Similarly, Song (2016a) investigated language practices that Korean immigrant families employ at home for their children's HL learning and found that their practices were used purposefully by parents in support of their children's HL development. In another study (Song, 2016b), hybrid language practices, such as translanguaging practices encouraged by Korean parents at home were presented as a way to foster children's heritage language maintenance. Understanding these home language and literacy practices is important as it can inform educators of specific ways to support children's bilingualism through strategies and resources that are utilized successfully in the home (Li, 2006; Moll, Amanti, Neff, \& Gonzalez, 1992). Often, educators do not have opportunities to learn about and understand the home practices of linguistically and culturally diverse learners. Some educators view family practices, particularly home language practices of immigrant children, through a deficit perspective and consider them as barriers to the students' success. Some even consider these children as in need of being "linguistically fixed or repaired" (García \& Kleifgen, 2018, p. 137). Hence, it is important that we pay close attention to specific strategies and practices that immigrant parents employ at home and inform educational researchers to understand effective ways of supporting children's biliteracy development through fostering their heritage language.

\section{B. Korean Immigrant Parents' Beliefs toward Heritage Language Learning}

Immigrant parents' perception toward their children's heritage learning are significant factors for their children's HL maintenance and learning because, as Tse (2001) asserts, parents play important roles as HL gatekeepers for their children:

Parents are in many ways "gatekeepers" to the heritage language: whether parents speak to their children in the native language; the attitudes parents hold about maintenance of the language; whether opportunities are sought out for the child to be exposed to or to formally study the language; and whether parents provide reading materials in the home or model uses of literacy (...); all may have an impact on whether and to what extent the language is retained by children (Tse, 2001, p. 37).

Previous studies demonstrate that for a number of reasons, Korean immigrant parents have a strong desire to develop and maintain their children's heritage language proficiency (Lee, 2013; Park \& Sarkar, 2007; Song, 2016a). Many Korean immigrants pursue their children's heritage language maintenance because they believe it plays a crucial role in their children's identity formation and understanding of their ethnic culture (Kang, 2013; Lee, 2013; You, 2005). Given that language, culture, and identity are intertwined, heritage language proficiency can indeed lead to a strong sense of ethnic identity in children. Moreover, children who are fluent in their heritage language tend to maintain close relationships with both intergenerational families and members of their ethnic minority group (Cho, 2000; Kang, 2013). In addition, Korean parents perceive bilingual competency in both Korean and English to be a key asset for their children's future. They believe it will lead to more educational and career opportunities than those available to their children's monolingual counterparts (Kwon, 2017; Lee, 2013). While these studies highlight the desire among Korean parents to pass down their HL to subsequent generations, little is known about the specific strategies and teaching 
methods they use at home, or the barriers they face in fostering their children's bilingual learning and biliteracy development.

\section{Korean Immigrant Parents' Practices to Maintain Heritage Language}

As a result of the numerous sociocultural and personal benefits that HL brings to children, many Korean immigrant parents strive to support their children's heritage language development and maintenance. Previous studies (Park \& Sarkar, 2007) demonstrate how Korean immigrant parents are actively engaged in the local ethnic community or ethnic church in order to provide their children with opportunities to interact with Koreans and improve their Korean in a natural setting. Enrolling children in a local heritage language school is another common practice to foster their children's heritage language learning (Kang, 2013; Kim, 2011). Many Korean immigrant parents rely on heritage language school not just for teaching language and culture, but also for supporting their children's integration into society. For example, in a study with seven Korean mothers, Kim (2011) found that the mothers see heritage language school as an important learning space that serves as a social and emotional support system, a way to reduce detachment anxiety from parents, and a safety net for their children's challenging immigrant lives. While some studies have been carried out in heritage language school settings (Kim, 2011; You, 2005), there is a paucity of research on how heritage language learning takes place at home. More to the point, literacy practices and the environments of Korean families are a relatively underexplored area.

\section{Methodology}

\section{A. Context and Participants}

In the southern region of Virginia where the study was conducted, the percentage of ethnic Koreans is less than .02\% of the 1.6 million regional population (U.S. Census Bureau, 2017). It is estimated that there are about 800 Korean language speaking households in this area. As a member of the community, the first author has identified and observed a variety of educational practices used by Korean immigrant parents at home in support of their children's HL learning, despite the limited ethnic cultural resources available in the community. Therefore, this location was intentionally chosen to examine how Korean immigrant parents raise their children learning Korean in a community with limited Korean ethnic and cultural resources.

This study used convenience subjects of 45 Korean mothers or fathers who were easily accessible and joined this study voluntarily. Data for this study were collected from 40 mothers or fathers representing 40 households residing in southeastern Virginia, omitting data from 5 households who returned incomplete questionnaires.

TABLE 1.

DEMOGRAPHICS OF PARTICIPATING HOUSEHOLDS $(N=40)$

\begin{tabular}{lll}
\hline & $N$ & \\
\hline Nationality & Mother & Father \\
South Korea & 34 & 29 \\
USA & 4 & 10 \\
Other & 2 & 1 \\
Parents' First Language & Mother & Father \\
Korean & 36 & 32 \\
English & 3 & 8 \\
Korean and English & 1 & \\
& & \\
Dominant Language at Home & & \\
Korean & 15 & \\
English & 8 & \\
Korean and English & 17 & \\
\hline
\end{tabular}

Table 1 shows demographic data of the 40 Korean households where one or both parents are immigrants from South Korea. Either the mother or father of each of the 40 households completed the questionnaire. The participants were recruited through local Korean community networks, including Korean heritage language schools, small businesses, and Korean churches located in the region.

The majority of mothers ( 34 out of 40) and fathers (29 out of 40) in this study, apart from a few who were born in the U.S. or other countries, are originally from Korea and immigrated to the United States for reasons including family migration, study abroad, work, or marriage.

Mean length of residence in the USA was 18 years for mothers and 24 years for fathers. The mothers' age ranged from 37 to 55, and the fathers' age was between 37 and 63. Most of the participants (31 out of 40) identified themselves as middle SES. Most of the participants (30 out of 40) indicated that they hold bachelors or higher degree ( 9 doctoral degree, 5 master's, and 16 bachelor's degrees) with an annual income of more than $\$ 60,000$. Their education level and income can be served as an indicator of the middle-class households. 
The majority $(52.5 \%)$ of the participant parents have two children, while $35 \%$ have one, and $12.5 \%$ have three. The mean age of first and second children was $12.26(\mathrm{SD}=3.74)$ and $9.46(\mathrm{SD}=3.77)$, respectively. While 17 out of 40 parents responded that they use both Korean and English flexibly at home, 15 out of 40 parents said they use Korean as their dominant language at home. This data indicated that the children of the majority (32 out of 40) have the opportunity to speak Korean. Eight parents indicated a preference for using only English at home. Parents who expressed an interest in participating in further in-depth, semi-structured interviews were contacted for interviews. Table 2 shows demographics of five interview participants.

TABLE 2.

DEMOGRAPHICS OF INTERVIEWEES $(\mathrm{N}=5)$

\begin{tabular}{|c|c|c|c|c|c|}
\hline Name & Hayoung & Jinah & Minju & Yunha & Eunju \\
\hline Age & 42 & 46 & 43 & 38 & 37 \\
\hline Birth Place & Korea & Korea & Korea & Korea & Korea \\
\hline Profession & Housewife & Realtor & Housewife & Professor & Housewife \\
\hline $\begin{array}{l}\text { Immigration } \\
\text { History }\end{array}$ & 6 years ago & 20 years ago & 18 years ago & 9 years ago & 12 years ago \\
\hline $\begin{array}{l}\text { Language Spoken } \\
\text { at Home }\end{array}$ & Korean & Korean & Korean & Korean & Korean \\
\hline $\begin{array}{l}\text { Age and Gender of } \\
\text { Child(ren) }\end{array}$ & $\begin{array}{l}\text { 15-year-old (female) } \\
\text { and } \\
8 \text {-year-old (female) }\end{array}$ & $\begin{array}{l}\text { 18-year-old (male) } \\
\text { and 15-year-old } \\
\text { (female) }\end{array}$ & $\begin{array}{l}\text { 16-year-old (female) } \\
\text { and } 12 \text {-year-old } \\
\text { (male) }\end{array}$ & 7-year-old (male) & 10-year-old (male) \\
\hline
\end{tabular}

\section{B. Data Collection}

To understand Korean immigrant parents' perspectives and practices for children's HL maintenance, we collected responses from open-ended questionnaires and in-depth face-to-face interviews with the Korean immigrant parents. The questionnaires in appendix 1 consisted of three sections, including family demographics (e.g., age, migration history, level of education, etc.), bilingual education beliefs, and heritage language and literacy practices used at home. Each section, aside from the demographic section, included open-ended questions that guided the parents to think about their beliefs and practices. The questionnaires were drawn from review of the literature and verified with several bilingual education experts who are fluent in both Korean and English using a recursive process. The questionnaires were provided in dual language and responses were also collected either Korean or English. While collecting the written responses to the questionnaires, we took field notes to document any qualifying statements from authentic conversations with the participants.

Appendix 2 lists the specific questions that guided our semi-structured interviews. The majority of our interview questions were "grand tour" questions that focused on the parents' perceptions and practices (Spradeley, 1979, p. 88). All names of interview participants used in the paper are pseudonyms to protect confidentiality. Each interview was conducted in Korean for better communication in person and lasted approximately one hour. All interviews were audiorecorded and later transcribed verbatim. Interviewees were asked about their beliefs regarding the importance of teaching Korean to their children and specific strategies they use for teaching HL to their children at home.

\section{Data Analysis}

This qualitative study analyzed multiple data sources including responses to an open-ended questionnaire, interview transcripts, and field notes. After organizing the data, we identified repeatedly used phrases and recurring patterns. We then immersed ourselves in interview data, reading carefully the participants' responses to our in-depth, open-ended questions (Marshall \& Rossman, 2006), and wrote down comments, ideas, and questions during the iterative reading process (Cresswell, 2007). After discussing and comparing similarities and differences in the themes and sub-themes identified, we arrived at a consensus for the final themes. We used open coding (Miles \& Huberman, 1994) and assigned codes based on our research questions and review of the literature. After developing a list of initial codes, we matched them again with questionnaire data and identified categories and themes across multiple sources of data. To enhance trustworthiness of the analysis, data triangulation was completed by member checking (Cresswell \& Miller, 2000; Fraenkel \& Wallen, 2003). We discussed the themes and sub-themes identified through careful readings of the content of the multiple sources of data until we arrived at a consensus for the final themes.

\section{FINDINGS}

In this section, we discuss several themes and sub-themes we identified across multiple sources of data. The first section, Parents as HL Advocates, highlights parents' strong beliefs in heritage language maintenance and helping 
children see the value of learning HL. In the second section, Parents as Heritage Language Teachers, we address how Korean immigrant parents create an HL learning environment, teach HL reading and writing, and use popular culture and digital media as mediums of instruction.

\section{A. Parents as Heritage Language Advocates}

Parents' Beliefs toward Heritage Language Maintenance. With respect to Korean immigrant parents' beliefs about bilingual education, the vast majority (38 out of 40 participant parents) shared their firm belief in the importance of developing their children's HL. This is consistent with previous studies (Kang 2013; Kwon, 2017) that illustrated Korean immigrant parents' emphasis on heritage language development. The participants believed that HL is beneficial for the practical purpose of increased job opportunities. More importantly, the parents also emphasized close ties with family members and a strong ethnic identity as important benefits of HL maintenance.

When asked the reasons for their positive views on heritage language maintenance, 15 parents responded that learning Korean allows their children to better communicate with their parents, grandparents, and extended families in Korea. They also shared their concerns that the loss of HL can have a disruptive impact on family relations and communication between parents and children. This concern was more frequently brought up by first-generation immigrant mothers born in Korea, and mothers who are not fluent in English. For example, Hayoung, an immigrant mother who moved to the United States 6 years ago, shared her fear of being unable to communicate with her children as she notices her second child, an 8-year-old daughter, becoming more comfortable speaking in English:

My daughters listen and obey me now. When they grow up and become rebellious, what will happen? I am scared that if my children refuse to learn Korean as they grow up. I will not understand their inner thoughts and not be a capable problem-solving partner and thinking partner for my daughters.

Her concern was shared by other focal parents who are strong proponents of teaching HL, as illustrated in the following quote. Jinah, noted:

Honestly, I teach Korean to my children for a selfish reason. I want my children to speak Korean with me for my own needs. I never had a chance to learn English, and my English is not fluent. For my own communication needs, my children should not lose Korean."

Minju who emigrated to the U.S. 18 years ago, stated there were many occasions where she found it difficult to communicate with her two children, a 16-year-old daughter and 12-year-old son. She had to ask her children to repeat things they said in English or ask them questions for clarification. She was concerned about not being able to communicate with her children in the future due to language barriers. She also mentioned that the loss of HL would "disrupt the emotional connection" with them. Her concern has motivated her to teach her child Korean and she has told her child, "You have to learn Korean because my English is not fluent."

Parents who are not comfortable and lack confidence in using English tend to rely more on their children's acquisition of Korean than their own acquisition of English, especially in an area with a limited number of Korean speakers. This finding shows how immigrant parents share the belief that children's HL fluency is primarily what helps the families maintain a close intergenerational relationship and engage in effective familial communication.

Helping Children See the Value of Heritage Language Learning. We found that the majority of Korean parents (38 out of 40) believe that they are responsible for their children's HL learning. Two of the interviewees interestingly stated that HL teaching is "a mother's" responsibility. Korean parents' strong belief that they are the most influential teacher who can help children see the value of learning HL may stem from their view that "home is the only environment where a child can learn Korean," especially in a community where English is seen as standard language and Korean as a nonfunctional language without use. Previous studies corroborate this belief by showing that parents play an important role as key agents in developing children's bilingualism (Kang, 2013).

Some parents (11 out of 40) express to their children how important it is to know their heritage culture and establish their Korean identity. They reported that a primary motivation for teaching heritage language to their children is the building of a strong sense of ethnic identity in their children. All five interview participants commented that maintaining their heritage culture and traditions is one of the ways to build an ethnic identity for their children. One of the mothers, Yunha, said her 7-year-old son considers himself "American" rather than "Korean." However, both she and her husband believe that teaching him the Korean language is "not an option, but mandatory" because it will help their child to have pride in his culture and grow with a stronger ethnic identity. She said, "I tell him that he must learn Korean because the fact that he is Korean does not change although he was born in the U.S." These parents' beliefs align with assertions that children, through learning a heritage language, can gain a better understanding of their heritage culture and therefore preserve their heritage identity (Brown, 2011; Park \& Sarkar, 2007; Cavallaro, 2005). Our findings indicate the parents believe HL maintenance enhances not only ethnic identity construction, but also bicultural understanding and positive views on bicultural identities (Cho \& Krashen, 1998; Lee, 2002).

Challenges of Heritage Language Maintenance. Parents in this study shared that they encounter many barriers in supporting their children's heritage language maintenance and learning. Parents (11 out of 40) agreed that living in a region where English is considered the norm places pressure on their children to focus on achieving English proficiency over Korean language. These parents pointed out their children's limited exposure to heritage language environment in their school and community, as the city has a low population of Korean immigrants. The parents stated that "They (children) are predominantly exposed to the environment where speaking in English is required," and "there is no 
opportunity to use Korean." One of the interview participants, a mother of a 7-year-old son, commented, "living in the U.S. itself makes it difficult to teach heritage language. Once you step outside your door, everyone you meet speaks English." Another mother pointed out that it would have greatly benefited her child if the school had offered Korean as a foreign language and said, "My son's school offers a lot of different options for foreign language class such as Spanish, Chinese, Japanese, and French; but Korean is not an option." Another mother echoed this opinion, stating that her child spends most of her day using English, as she does so when socializing with her friends. For these reasons, interview participants indicated that they feel a stronger sense of responsibility to teach HL at home. They added that this is the reason they enroll their children in a local heritage language school, a place where children will be exposed to the Korean language and culture. The four heritage language schools in the local community were highly valued by participant parents and described as "well-structured" and "educative." However, given that the schools offer classes only once a week, parents felt the need for additional HL programs.

Furthermore, the participants pointed out that lack of motivation is primarily what hinders their children from maintaining Korean. Given that the children are predominantly exposed to an all-English environment and have little time to study Korean, they often feel like giving up on learning their HL. Two parents explained that it is difficult for their children to maintain their motivation when there is "excessive homework," "busy school work," and "no time to work on Korean." Korean-American children tend to stop using their HL and become unmotivated as they feel pressure to learn English in an all-English environment. Considering the challenges that mothers in this study described, it is important that parents play an active role at home as HL educators by exposing their children to greater numbers of HL materials and opportunities to use and learn Korean.

\section{B. Parents as Heritage Language Educators}

The results reveal that Korean parents, residing in a region with a small Korean population, participate and engage in a wide range of educational practices at home to foster their children's heritage language development just as actively as their counterparts living in a large Korean community. These practices include practicing HL reading and writing, utilizing HL popular culture and media, and creating an HL learning environment. It is noteworthy that Korean parents engage their children in shared reading activities and journal writing for HL learning purposes. The findings of this study urge educators to view immigrant parents as essential partners in their children's bilingual and bicultural learning. It also highlights the need for encouraging parents to continue to engage their children in these language and literacy activities at home.

Creating an HL Learning Environment to Use Korean Consistently. Of the 40 participants, 8 parents reported that they use English only when communicating with their children. Others stated that they either speak only Korean or use both Korea and English with their children. They indicated that their purposeful use of Korean for casual conversation is to naturally expose their children to their HL. All five interview participants also stated that they intentionally speak Korean at home to create a positive learning environment. For instance, Jinah, who strongly believes "family conversation always need to be in Korean," remarked that she and her husband intentionally use the Korean language at home in order to encourage their children to use the HL. Several parents explained that they had established the use of a family language policy (King, Fogle, \& Logan-Terrey, 2008) where they explicitly and implicitly plan language use in home settings. Yunha, for example, mentioned that her family has "basic rules" not only to speak just Korean, but also to follow Korean customs, such as bowing to their elders to show respect. A few mothers explained that they alternate between English and Korean when communicating with their children. Minju, for example, stated that she uses English when helping her child with homework and explaining difficult concepts, such as fractions. In another context such as casual conversations and text messaging, she intentionally uses Korean to expose her child to an HL learning environment. While Korean was used as a primary language for communication, English also was incorporated to scaffold children's academic learning.

HL Reading and Writing Instruction at Home. Parents in this study acknowledged the necessity of developing HL reading and writing of their child or children. A majority (32 out of 40) reported that they engage in an array of practices at home for fostering their children's reading and writing in Korean. One of the parents noted that reading and writing in HL is "a basic skill" that her child needs. When parents were asked how they teach HL to their children, a majority of participants confirmed that they either regularly encourage their children to read Korean books (12 out of 40) or read books to them (13 out of 40). The participants also explained that they purchase and read Korean books to their children. A majority of participants shared that they have more than 30 books at home that are either written in Korean or about Korean culture. Because there is a limited number of HL materials (e.g., children's books, teaching materials) available in public and school libraries, several parents stated that they share and rotate books with other Korean families in the community.

Interview participants noted that the books they have about Korean language and culture written in Korean were either purchased during their trips to Korea or brought back by their relatives. One of the mothers, Eunju, had more than 100 books written in Korean, which exceeds the number of English books she has for her son. She explained that she purchases picture books and chapter books whenever she visits Korea. Yunha, who does not have many chances to visit Korea, shared that whenever her extended family visits the U.S., she asks them to bring some children's books, which she reads to her child two or three times a week. 
One of the mothers explained that she encourages her child to write journal entries in Korean on a regular basis, which she believes is an effective way to develop her child's HL writing skills. Her strategy stemmed from her own experiences of learning and maintaining Korean when she lived in the U.S. for a few years as a child. She described her experience as follows:

My parents used to make me write journal entries in Korean when I was young. Then my family moved back to Korea when I was in the 3rd grade. Because I practiced writing in Korean a lot, I soon adapted to the new environment when I returned to Korea.

Other mothers also echoed that parent-guided HL writing activities help their children develop good HL writing habits as well as their HL writing skills.

Participants also noted that they intentionally use media to expose their children to Korean movies and television programs. In the questionnaires, the majority of Korean parents (35 out of 40) reported that they frequently encourage their children to watch or listen to Korean popular culture and media channels such as music videos on YouTube, comedies, documentary shows, and cartoons. During the in-depth interviews, all five mothers noted that heritage popular culture and media is a great resource for their children to learn Korean. One of the mothers, Yunha, emphasized that her family routinely watch Korean television programs two or three times a week to ensure her son's Korean learning. She said, "I try to watch Korean television with my child as much as possible because it motivates him to learn Korean. He asks us questions about words and expressions to understand the TV shows." Similarly, Eunju explained that her family "tries to watch Korean television programs regularly" because it motivates her child to learn Korean. Just as for these two families, exposure to Korean media stimulated children's curiosity leading them to raise questions about vocabulary and expressions in order to understand meaning within context.

\section{DiSCUSSION \& IMPLEMENTATIONS}

We investigated Korean immigrant parents' beliefs and the home practices they engage in to raise bilingual and biliterate children. Specifically, we examined Korean immigrants' perspectives concerning their children's HL development and explored their experiences of teaching their heritage language at home. The participating parents believe that in addition to acquiring the English language naturally, their children need to learn their heritage language, at least at home, simultaneously. This finding reflects results reported by previous studies (Cho, 2000; Han, 2012; Li, 2002; Kwon, 2017; Park \& Sarkar, 2007) which revealed the strong tendency of immigrant parents to raise their children to be bilingual and bicultural.

Parents in this study highlighted that learning Korean can help a child better communicate with parents as well as relatives in Korea. This finding mirrors results reported by (Brown, 2011; Kwon, 2017; Park \& Sarkar, 2007) which found that heritage language is a necessary conduit between parents and children, and an important medium of communication among immigrants in an adopted country. It is important to urge that parents with limited English proficiency invest more in cultivating their children's HL skills so that they can communicate with their children in Korean. Immigrant parents should understand the importance of speaking HL with their children at home to increase the chance of successfully teaching their HL (De Houwer, 2007). Immigrant parents should use whichever language they are proficient with when teaching HL which will support their children maintaining their HL currently and for many generations to come.

Korean parents take responsibility for their children's HL learning. Participant parents explained that the scarcity of resources on Korean and their children's limited exposure to Korean, Korean books, and learning opportunities make their roles as HL educators much more imperative. This can be explained in part by the lack of HL support from mainstream public schools, which leads immigrant parents to assume sole responsibility for their children's HL maintenance (Hinton, 1999 cited in Park \& Sarkar, 2007; Lao, 2004, Li, 1999), especially in a region with a small Korean population. The participants shared that they face many challenges as they support and maintain their children's heritage language (DeCapua \& Wintergerst, 2009). Living in an English-dominant society gives few opportunities for language minority children to be exposed to HL or learning materials. Moreover, as English is the only language of critical use and heavily emphasized in school and society, children easily lose motivation to develop their HL. Hence, it is important that schools and communities work collaboratively with parents in supporting children's HL development (Cummins, 2001; Kondo, 1998).

This qualitative study has significance as it contributes to the ongoing conversation about immigrant children's bilingualism and suggests implications for practice and research. Our study provides several implications to teachers and administrators of heritage language schools. Given that immigrant parents play significant roles as their children's HL teachers and advocates, it is important that heritage language schools partner with immigrant families who possess broad knowledge and effective strategies useful for cultivating children's bilingualism and biliteracy. For instance, gathering parents' perspectives, strategies, and practices concerning children's HL through questionnaires at the beginning of each semester will allow teachers to create a HL curriculum that is linguistically and culturally responsive. We also suggest HL school administrators organize events and groups where immigrant parents can share literacy materials and advice for children's heritage language learning. The findings also imply that it is important for teachers in mainstream schools to encourage immigrant children and their families to continue supporting HL learning at home. 


\section{CONCLUSION}

Parents who speak a language other than English can enrich their immigrant children's language and literacy experiences by providing them with extensive exposure to multiple languages and cultures and utilizing an array of HL teaching practices at home. This study is significant as it examines an area with a low density of Koreans, yet a relatively large number of families participated in the study that paid close attention specific HL teaching strategies they use at home. Participants in this study have shown that Korean parents are advocates for their children learning and maintaining their HL despite the fact that they reside in an English dominant community with a small Korean population, limited HL resources, and schools with very little HL support.

We illustrated Korean parents' efforts to raise their children to be bilingual and bicultural. This includes: enforcing home language policy, exposing children to Korean media, and instructing reading and writing at home. The parent's conscious efforts to develop simultaneous bilingualism can help children maintain their HL and cultural heritage as well as increase intergenerational dialog within the immigrant family and between the extended families overseas. It is, therefore, important that parents continue to enrich children's heritage language learning by using reading and writing strategies, creating an HL environment, and introducing children to their ethnic culture. In addition, we argue that mere exposure to Korean at home or HL school is not enough for children to maintain their HL and acquire high Korean language proficiency. This study confirms that "cross-context collaboration" (Li \& Wen, 2015) is imperative, where families, mainstream schools, and local ethnic communities collaboratively support immigrant children's heritage language learning and create a positive environment where linguistic diversity is valued.

\section{APPENDiX I. OPEN-ENDED Korean Home BILINGUAL EDUCATION QUESTIONNAIRES}

\section{A. Family Demographic Information 가족 구성원에 관한 정보}

Number of people in the family: 가족 구성원 수

Number of children in the family: 가족 중 자녀 수

Household gross annual income (combine all income): 가족 총 수입

What is the native language of the mother? 어머니의 모국어는 무엇입니까?

What is the native language of the father? 아버지의 모극어는 무엇입니까?

Father's and Mother's age: 아버지, 어머니의 나이

Father's reason for coming to the U.S.: 아버지, 어머니의 미국에 온 이유

Father's Highest Level of Education: 아버지,어머니의 최종 학력

Father's number of years living in USA: 아버지, 어머니의미국 생활 년 수

Child's dominant language(s) at home: 집에서 주로 쓰는 언어

Age of child (children): 자녀 나이

Birth place of child (children): 자녀 출생지

\section{B. Bilingual Education Beliefs: 이중 언어 교육에 관한 관점}

(1) Why or why not do you believe it is important for your child(ren) to learn Korean?

자녀가 한국어를 배우는 것이 중요하다고 믿는다면 또는 반대로 중요하지 않다고 생각한다면 각각 그 이유를 밝혀 주십시오.

(2) How do you help your child(ren) understand your beliefs regarding the value of learning Korean? What do you tell your children to help them believe in the value of learning Korean?

자녀들이 한극어를 배우는 가치에 관한 당신의 믿음을 어떻게 이해시키십니까? 자녀에게 한극어를 배우는 것이 가치 있다고 믿을 수 있도록 어떤 말을 해 주십니까?

(3) How do you and your spouse agree or disagree about your child(ren)'s learning Korean? Explain with an example.

당신과 배우자는 자녀가 한국어를 배우는 것을 동의 하십니까? 예 를 하나 들어 설명하십시오.

(4)Who is primarily responsible for teaching Korean to your child(ren)?

자녀에게 한국어를 가르치는 사람은 주로 누구책임입니까?

\section{Heritage Language and Literacy Practices: 모국어 가르치기}

(1) How do you support your child(ren)'s learning Korean? List any teaching activities you have used to teach the heritage language?

당신의 자녀가 한국어를 배우는 것을 어떻 게 지원하십니까? 가르치는 방법을 나열하십시오.

(2) What obstacles do you have in encouraging your child(ren) to learn Korean? How do you overcome those obstacles?

자녀들이 한국어를 배우는 것을 돕는 일에 방해되는 일이 있나요? 있다면 어떻게 극복하십니까? 
(3) Do you have any other recommendations for immigrant families who want their children to learn Korean? 당신은 자녀가 한국어를 배우기 원하는 이 민자 가정에게 추천하고 싶은 것이 있습니까?

(4) How do you help your child(ren) read Korean books at home?

당신은 자녀가 한국어 서적을 읽는데 어떻게 돕 습니까?

(5) How do you expose your children to Korean movies / video clips / news in Korean at home? 자녀들이 한극영화나 동영상, 뉴스를 집에서 얼마나 자주 볼 수 있게 합니까?

\section{APPENDIX II. INTERVIEW QUESTIONS}

How important is it for your children to learn and maintain their Korean?

What do you do to support your child(ren) learning Korean?

What difficulties have you had supporting your children's Korean learning?

How types of Korean books and media do you expose your children to?

How frequently did your family visit your home country in a year and for what period?

Do you have any specific strategies you have adopted to help your children to learn Korean?

Is there another person who teach Korean to your children at home?

\section{REFERENCES}

[1] Brown, C. L. (2011). Maintaining heritage language: Perspectives of Korean parents. Multicultural Education, 19(1), 31-37.

[2] Budiyana, Y. E. (2017). Students' parents' attitudes toward Chinese heritage language maintenance. Theory and Practice in Language Studies, 7(3), 195-200. doi: http://dx.doi.org/10.17507/tpls.0703.05.

[3] Cavallaro, F. (2005). Language maintenance revisited: An Australian perspective. Bilingual Research Journal, 29(3), 561-582. doi: 10.1080/15235882.2005.10162852.

[4] Choi, J. Y., Lee, J. S., \& Oh, J. S. (2018). Examining the oral language competency of children from Korean immigrant families in English-only and dual language immersion schools. Journal of Early Childhood Research, 16(1), 32-51. doi: $10.1177 / 1476718 X 15610597$.

[5] Cho, G. (2000). The role of heritage language in social interactions and relationships: Reflections from a language minority group. Bilingual Research Journal, 24(4), 369-384. doi: 10.1080/15235882.2000.10162773.

[6] Cho, G. and Krashen, S. (1998). The negative consequences of heritage language loss and why we should care. In S. Krashen, L. Tse, and J. McQuillan (Eds.) Heritage Language Development (pp. 31-39). Culver City, CA: Language Education Associates.

[7] Cho, G., Cho, K., \& Tse, L. (1997). Why ethnic minorities want to develop their heritage language: The case of KoreanAmericans. Language, Culture and Curriculum, 10(2), 106-112. doi: 10.1080/07908319709525244.

[8] Cresswell, J. W., \& Miller, M. D. (2000). Determining validity in qualitative inquiry. Theory into Practice, 39(3), 124-130. doi: 10.1207/s15430421tip3903_2.

[9] Cresswell, J. W. (2007). Qualitative inquiry \& research design: Choosing among five approaches (2nd ed.). Thousand Oaks, CA: Sage.

[10] Cummins, J. (2001). Heritage language teaching in Canadian schools. In C. Baker and N.H. Hornberger (Eds.) An Introductory Reader to the Writings of Jim Cummins (pp. 252-257). Clevedon, United Kingdom: Multilingual Matters.

[11] DeCapua, A., \& Wintergerst, A. C. (2009). Second-generation language maintenance and identity: A case study. Bilingual Research Journal, 32(1), 5-24. doi: 10.1080/15235880902965672.

[12] De Houwer, A. (2007). Parental language input patterns and children's bilingual use. Applied Psycholinguistics, 28(3), $411-424$. doi:10.1017/S0142716407070221 de Jong, E. J. (2011). Foundations for multilingualism in education: From principles to practices. Philadelphia, PA: Calon Publishing.

[13] Fishman, J. (2001). 300? years of heritage language education in the United States. In J. K. Peyton, D. A. Ranard, \& S. McGinnis (Eds.), Heritage languages in America: Preserving a national resource (pp. 81-97). McHenry, IL: Delta Systems.

[14] Fraenkel, J., \& Wallen, N. (2003). How to design and evaluate research in education (5th ed.). New York: McGraw-Hill.

[15] García, O., \& Kleifgen, J. (2018). Educating Emergent Bilinguals: Policies, Programs, and Practices for English Learners (2nd ed.). New York, NY: Teachers College Press.

[16] Han J., \& Neuharth-Pritchett, S. (2014). Parents' interactions with preschoolers during shared book reading: three strategies for promoting quality interactions. Childhood Education, 90(1), 54-60. doi: 10.1080/00094056.2014.872516.

[17] Han, W. J. (2012). Bilingualism and academic achievement. Child Development, 83, 300-321. doi: 10.1111/j.14678624.2011.01686.x.

[18] Jia, G., Chen, J., Kim, H. Y., Chan, P. S., \& Jeung, C. (2014). Bilingual lexical skills of school-age children with Chinese and Korean heritage languages in the United States. International Journal of Behavioral Development, 38(4), 350-358. doi: $10.1177 / 0165025414533224$.

[19] Jo, J. O., \& Lee, S. (2016). Heritage language sustainability and transnational affect: Thecase of second-generation Korean American. In X .L. Rong., \& J. Hilburn (Ed.), Immigration and Education in North Carolina: The challenges and responses in a new gateway state (pp. 221-240). Sense Publishers: Rotterdam.

[20] Kang, H. (2013). Korean-immigrant parents' support of their American-born children's development and maintenance of the home language. Early Childhood Education Journal, 41, 431-438. doi: 10.1007/s10643-012-0566-1.

[21] Kim, J. (2011). Korean immigrant mothers' perspectives: The meanings of a Korean heritage language school for their children's American early schooling experiences. Early Childhood Education Journal, 39(2), 133-141. doi: 10.1007/s10643012-0566-1. 
[22] King, K. A., Fogle, L., \& Logan-Terry, A. (2008). Family language policy. Language and Linguistics Compass, 2(5), 907-922. doi: 10.1111/j.1749-818X.2008.00076.x.

[23] Kondo, K. (1998). Social-Psychological Factors Affecting Language Maintenance: Interviews with Shin Nisei University Students in Hawaii. Linguistics and Education, 9(4): 369-408. doi: 10.1016/S0898-5898(97)90006-1.

[24] Kwon, J. (2017). Immigrant mothers' beliefs and transnational strategies for their children's heritage language maintenance. Language and Education, 31(6), 495-508. doi: 10.1080/09500782.2017.1349137.

[25] Lao, C. (2004). Parents' attitudes toward Chinese-English bilingual education and Chinese-language use. Bilingual Research Journal, 28(1), 99-121. doi: 10.1080/15235882.2004.10162614.

[26] Lee, B. (2013). Heritage language maintenance and cultural identity formation: The case of Korean immigrant parents and their children in the USA. Early Child Development and Care, 183(11), 1576-1588. doi: 10.1080/03004430.2012.741125.

[27] Lee, J. S. (2002). The Korean language in America: The role of cultural identity in heritage language learning. Language, Culture and Curriculum, 15(2), 117-133. doi: 10.1080/07908310208666638.

[28] Lee, J. S., \& Wright, W. E. (2014). The rediscovery of heritage and community language education in the United States. Review of Research in Education, 38, 137-165.

[29] Law, S. (2015). Children learning Chinese as a home language in an English-dominant society. International Bilingual Education and Bilingualism, 18(6), 735-748. doi: 10.1080/13670050.2014.946399.

[30] Li, G., \& Wen, K. (2015). East Asian heritage language education for a plurilingual reality in the United States: Practices, potholes, and possibilities. International Multilingual Research Journal, 9(4), 274-290. doi: 10.1080/19313152.2015.1086623.

[31] Li, G. (2006). Biliteracy and trilingual practices in the home context: Case studies of Chinese-Canadian children. Journal of Early Childhood Literacy, 6(3), 355-381. doi: 10.1177/1468798406069797.

[32] Li, G. (2002). "East is east, west is west"? Home literacy, culture, and schooling. New York: NY, Peter Lang.

[33] Li, X. (1999). How can language minority parents help their children become bilingual in familial context? A case study of a language minority mother and her daughter. Bilingual Research Journal, 23(2\&3), 113-125. doi: $10.1080 / 15235882.1999 .10668687$.

[34] Lu, X. (2001). Bicultural identity development and Chinese community formation: An ethnographic study of Chinese schools in Chicago. Howard Journal of Communication, 12, 203-220. doi: 10.1080/106461701753287723.

[35] Marshall, C., \& Rossman, G. (2006). Designing qualitative research (4th ed.). Thousand Oaks, CA: Sage.

[36] Miles, M. B., \& Huberman, M. (1994). Qualitative data analysis: An expanded sourcebook. Thousand Oaks, CA: Sage.

[37] Moll, L., Amanti, C., Neff, D., \& González, N. (1992). Funds of knowledge for teaching: Using a qualitative approach to connect homes and classrooms. Theory into Practice, 31(2), 132-141. doi: 10.1080/00405849209543534.

[38] Park, S., \& Sarkar, M. (2007). Parents' attitudes toward heritage language maintenance for their children and their efforts to helped their children maintain the heritage language: A case study of Korean-Canadian Immigrant. Language, Culture and Curriculum, 20(3), 223-235. doi: 10.2167/lcc337.0.

[39] Polinsky, M., \& Kagan, O. (2007). Heritage languages: In the 'wild'and in the classroom. Language and Linguistics Compass, 1(5), 368-395.

[40] Ro, Y. E., \& Cheatham, G. A. (2009). Biliteracy and bilingual development in a second-generation Korean child: A case study. Journal of Research in Childhood Education, 23(3), 290-308. doi: 10.1080/02568540909594662.

[41] Sánchez-Muñoz, A. (2016). Heritage language healing? Learners' attitudes and damage control in a heritage language classroom. In D. Pascual y Cabo (Ed.) Advances in Spanish as a heritage language (pp. 205-217). Amsterdam, The Netherlands: John Benjamins Publishing Company.

[42] Shibata, S. (2000). Opening a Japanese Saturday school in a small town in the United States: Community collaboration to teach Japanese as a heritage language. Bilingual Research Journal, 24(4), 334-342. doi: 10.1080/15235882.2000.10162778.

[43] Shin, S. J. (2005). Developing in two languages: Korean children in America. Clevedon, United Kingdom: Multilingual Matters Ltd.

[44] Shin, S. J. (2002). Birth order and the language experience of bilingual children. TESOL Quarterly, 36(1), 103-113. doi: $10.2307 / 3588366$.

[45] Song, K. (2016a). Nurturing young children's biliteracy development: A Korean family's hybrid literacy practices at home. Language Arts, 93(5), 341-353.

[46] Song, K. (2016b). "Okay, I will say in Korean and then in American": Translanguaging practices in bilingual homes. Journal of Early Childhood Literacy, 16(1), 84-106. doi:10.1177/1468798414566705.

[47] Spradley, J. P. (1979). The ethnographic interview. New York, NY: Harcourt.

[48] Tse, L. (2001). "Why Don't They Learn English" Separating Fact from Fallacy in the U.S. Language Debate. New York, NY: Teachers College Press.

[49] U.S. Census Bureau (2017). Dp05: ACS Demographic and housing estimates, 2011-2015 American Community Survey 5-year estimates. Washington DC: U.S. Census Bureau's American Community Survey Office.

[50] Valdés, G. (2001). Heritage language students: Profiles and possibilities. In J. Peyton, D. Ranard, \& S. McGinnis (Eds.), Heritage languages in America: Preserving a national resource (pp. 37-77). Washington, DC: Center for Applied Linguistics Delta Systems.

[51] Wong Fillmore, L. (1991). When learning a second language means losing the first. Early Childhood Research Quarterly, 6, 323-346. doi: 10.1016/S0885-2006(05)80059-6.

[52] Yang, S., Yang, H., \& Lust, B. (2011). Early childhood bilingualism leads to advances in executive attention: Dissociating culture and language. Bilingualism: Language and Cognition, 412-422. doi: 10.1017/S1366728910000611.

[53] You, B. (2005). Children negotiating Korean American ethnic identity through their heritage language. Bilingual Research Journal, 29(3), 711-721. doi: 10.1080/15235882.2005.10162860.

[54] Zhang, D., \& Slaughter-Defore, D. T. (2009). Language attitudes and heritage language maintenance among Chinese immigrant families in the USA. Language, Culture and Curriculum, 22(2), 77-93. doi: 10.1080/07908310902935940. 


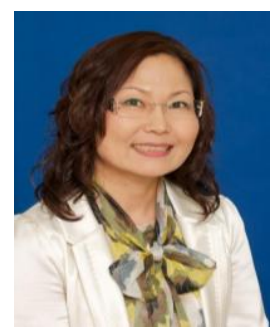

Guang-Lea Lee came to the United States of America in 1988 from her native country, South Korea and earned a Master's degree from Chicago State University, Chicago, Illinois in 1990 and a Ph. D. degree from the University of Minnesota, Twin Cities, Minnesota in 1993 in the area of literacy education.

She is a professor of literacy education and director of the Tidewater Writing Project in the Department of Teaching and Learning at Old Dominion University, Norfolk, Virginia, USA. She has trained teachers for 27 years in the higher education field after earning her $\mathrm{PhD}$ degree. She co-authored a textbook entitled, Multicultural Education of Children and Adolescents (Abingdon, United Kingdom, Routledge, 2017). Her professional interests and expertise include teacher education, influence of culture on literacy education, and educational issues of underrepresented students globally. Her research articles have been published in several prestigious journals, such as, Journal of Early Childhood Teacher Education, Childhood Education, Multicultural Education, Kappa Delta Pi Record, Journal of Research in Childhood Education, and International Journal of Early Childhood Education.

Dr. Lee has served as an editor and chair for several committees of the ACEI and a board member of the OMEP organizations. In addition, she has been a member of many professional societies and has made over 100 national/international presentations, including AERA, ILA, ACEI, NAEYC, NAECTE, OMEP, CRA, LRA, NCTE, NWP, NAME, World Congress on Reading, and Pan African Reading for All conferences.

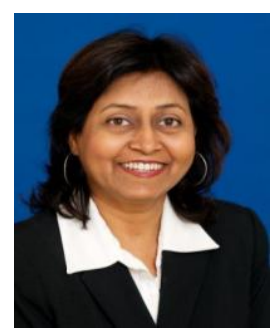

Abha Gupta received her M.A. in Linguistics and Ph.D. in Reading from the University of Arizona, Tucson, Arizona.

She is currently a Professor of Language and Literacy Education and the Graduate Program Director for Reading in the Department of Teaching and Learning at the Old Dominion University in Norfolk, Virginia. Her research includes literacy learning in culturally diverse environments and innovative interventions to promote literacy (see http://www.odu.edu/ agupta). Her publications have appeared in several leading journals related to literacy and teacher education. She has also co-edited two books on educational issues for at-risk population \& on empowerment of women and language.

Dr. Gupta has been an active member of the International Literacy Association (ILA), having served on its multiple special interest groups as well as on the National Commission on Urban Diversity, the National Title One Committee of ILA and the National Commission on Urban Initiatives in Education. Dr. Gupta has also co-chaired the Diversity Learning Committee and the Diversity Learning and Multiculturalism Committee of ILA. 